\title{
TRANSUTERINE MIGRATION OF SPERMATOZOA IN THE GOLDEN ,HAMSTER (MESOCRICETUS AURATUS)
}

\author{
G. LUBICZ-NAWROGKI \\ Unit of Reproductive Biology, University of Liverpool \\ (Received 13th May 1970)
}

In testing the fertilizing capacity of epididymal spermatozoa from the golden hamster under various experimental conditions, it was decided to determine the feasibility of placing spermatozoa in one uterine horn of a female in oestrus and depositing control spermatozoa in the contralateral horn of the same female. Although Hunter (1969) reported an insignificant degree of transuterine sperm migration in golden hamsters following unilateral intra-uterine deposition of spermatozoa towards the end of oestrus, the possibility remained that it might be more extensive during early oestrus. If, during this period, there is significant transmigration of spermatozoa from one uterine horn to the other, then clearly it is undesirable to examine two dissimilar samples of spermatozoa in one and the same female, despite the presence of a bipartite uterus where there is no uterine body and where the cervix is apparently divided by a septum (Hunter, 1969).

In the present work, epididymal spermatozoa were deposited into the left uterine horn of a female in oestrus by the method previously described by Yanagimachi \& Chang (1961). Following this, eggs were flushed from the Fallopian tubes with Hanks' solution between 30 and $36 \mathrm{hr}$ after ovulation, prepared as whole mounts and examined by phase contrast microscopy. The results are summarized in Table 1 . The mean number of eggs fertilized on the contralateral side following unilateral deposition of $16 \times 10^{6}$ or $22 \times 10^{6}$ spermatozoa was approximately $50 \%$ irrespective of whether the contralateral uterine horn was injected with an equal volume of sperm-free Hanks' solution at the time of sperm deposition. However, the number of eggs fertilized on the contralateral side was not the same in each female because, in some, only a proportion of the eggs was fertilized whereas in others, fertilization was $100 \%$. When $80 \times 10^{6}$ spermatozoa were deposited, all the eggs were fertilized on the contralateral side in each female.

By contrast, none of the eggs in the contralateral horn were fertilized when this horn was ligated before the unilateral deposition of spermatozoa (Table 1). In these experiments, transuterine sperm migration must have occurred by way of the cervix and not the peritoneal cavity. This is, perhaps, not surprising in view of the thick ovarian bursa in the hamster which envelops the infundibulum of the uterine tube. During early oestrus in the hamster, therefore, uterine spermatozoa can presumably be transported both anteriorly and posteriorly. 
Sperm transport to the uterine tubes can occur within $2 \mathrm{~min}$ of coitus in the hamster (Yamanaka \& Soderwall, 1960), but approximately $6 \mathrm{hr}$ are necessary to ensure a high level of fertilization (Yanagimachi \& Chang, 1963). No attempt was made here to determine the rate of sperm transport following unilateral deposition of spermatozoa, but in each case spermatozoa were placed in the uterine horns approximately $6 \mathrm{hr}$ before the ovulatory period, which, in the hamster, extends between 01.00 and 03.00 hours (Graves, 1945; Ward, 1946; Strauss, 1956). Thus, transuterine migration must have occurred within this time and also within the 4- to 6-hr period during which hamster eggs retain their fertilizing capacity (Chang \& Fernandez-Cano, 1958). It is not clear why the

\section{TABLE 1}

NUMBER OF FERTILIZED EGGS RECOVERED FROM BOTH UTERINE TUBES FOLLOWING UNILATERAL DEPOSITION OF SPERMATOZOA IN THE LEFT UTERINE HORN OF THE HAMSTER

\begin{tabular}{|c|c|c|c|c|c|c|c|c|c|}
\hline \multirow{2}{*}{$\begin{array}{l}\text { No. of } \\
\text { males }\end{array}$} & \multirow{2}{*}{$\begin{array}{l}\text { No. of } \\
\text { females } \\
\text { male }\end{array}$} & \multirow{2}{*}{$\begin{array}{l}\text { Spermatozoa } \\
\text { deposited } \\
\quad \times 10^{6}\end{array}$} & \multicolumn{2}{|c|}{$\begin{array}{c}\text { Mean no. of eggs } \\
\text { recovered } \\
\text { (with ranges) }\end{array}$} & \multicolumn{2}{|c|}{$\begin{array}{c}\text { Mean no. of } \\
\text { eggs } \\
\text { fertilized }\end{array}$} & \multicolumn{2}{|c|}{$\begin{array}{c}\text { Mean } \\
\text { fertilization } \\
\text { rate }(\%)\end{array}$} & \multirow{2}{*}{$\begin{array}{l}\text { Treatment of } \\
\text { right uterine } \\
\quad \text { horn }\end{array}$} \\
\hline & & & Left & Right & Left & Right & Left & Right & \\
\hline 2 & 4 & 16 & $\begin{array}{c}5 \cdot 8 \\
(3 \text { to } 9)\end{array}$ & $\begin{array}{l}5 \cdot 8 \\
(2 \text { to } 10)\end{array}$ & $5 \cdot 8$ & $3 \cdot 3$ & 100 & $53 \cdot 6$ & None \\
\hline 2 & 3 and 4 & 15 & $\begin{array}{c}4 \cdot 7 \\
(3 \text { to } 6)\end{array}$ & $\begin{array}{c}4-3 \\
(3 \text { to } 8)\end{array}$ & $4 \cdot 7$ & 1.8 & 100 & $43 \cdot 3$ & $\begin{array}{l}\text { Injected with } \\
\text { sperm free }\end{array}$ \\
\hline 1 & 5 & 22 & $\begin{array}{c}6 \cdot 4 \\
(5 \text { to } 8)\end{array}$ & $\begin{array}{c}4 \cdot 0 \\
(2 \text { to } 7)\end{array}$ & $6 \cdot 2$ & 1.8 & 97 & 45 & $\begin{array}{c}\text { Hanks' solution } \\
\text { None }\end{array}$ \\
\hline 1 & 4 & 80 & $\begin{array}{c}4.75 \\
(2 \text { to } 7)\end{array}$ & $\begin{array}{c}4 \cdot 5 \\
(4 \text { to } 5)\end{array}$ & $4 \cdot 75$ & $4 \cdot 5$ & 100 & 100 & None \\
\hline 1 & 4 & 15 & $\begin{array}{c}4.75 \\
(3 \text { to } 7)\end{array}$ & $\begin{array}{c}6 \cdot 0 \\
(4 \text { to } 11)\end{array}$ & $4 \cdot 75$ & 0 & 100 & 0 & Ligated \\
\hline
\end{tabular}

number of eggs fertilized in the contralateral tubes was inconsistent after using $22 \times 10^{6}$ spermatozoa. Presumably, the efficiency of migration differed in different animals.

When $80 \times 10^{6}$ spermatozoa were deposited in the uterine horn, it was found that three of the nineteen eggs recovered from the ipsilateral side $(16.0 \%)$ were polyspermic. Generally, the incidence of polyspermy in the golden hamster is only $1.08 \%$ (Austin, 1956), and this is thought to be due to a swift zona reaction (Austin, 1956). The greater incidence of polyspermy in the present experiments was probably due to the unusually large numbers of spermatozoa deposited rather than to delayed fertilization, since the phenomenon only occurred on the ipsilateral side where spermatozoa probably reached the uterine tubes before the eggs began to lose their fertilizing capacity, the time when polyspermy is most likely to occur.

Hunter (1969) noted that when spermatozoa were placed in one uterine horn towards the end of oestrus, less than $6 \%$ of the eggs in the contralateral side were fertilized. When this finding is compared with the present results, it suggests that the time during oestrus when spermatozoa are deposited profoundly influences the degree of transmigration. 
These present results show that, if the fertilizing capacity of hamster spermatozoa is to be tested by intra-uterine deposition, it is undesirable to examine two dissimilar samples in one and the same female without first ligating the uterine horns close to the cervix. This is particularly true at the beginning or in the middle of the oestrous period.

The work was financed by a grant from the Agricultural Research Council, and thanks are due to my supervisor, Dr T. D. Glover, for his help and interest.

\section{REFERENCES}

Ausris, C. R. (1956) Ovulation, fertilization and early cleavage in the hamster (Mesocricetus auratus). fl R. microsc. Soc. 75, 141.

Chang, M. G. \& Fernandez-Cano, L. (1958) Effects of delayed fertilization on the development of pronucleus and the segmentation of hamster ova. Anat. Rec. 132, 307.

Graves, A. P. (1945) Development of the golden hamster Cricetus auratus Waterhouse during the first nine days. Am. J. Anat. 77, 219.

Hunter, R. H. F. (1969) Capacitation in the golden hamster with special reference to the influence of the uterine environment. F. Reprod. Fert. 20, 223.

Strauss, F. (1956) The time and place of fertilization of the golden hamster egg. F. Embryol. exp. Morph. 4, 42.

WARD, M. C. (1946) A study of the oestrous cycle and breeding of the golden hamster (Cricetus auratus). Anat. Rec. 94, 139.

Yamanaka, H. S. \& Soderwall, A. L. (1960) Transport of spermatozoa through the genital tract of hamsters. Fert. Steril. 11, 470.

Yanagimachr, R. \& Ghang, M. C. (1961) Fertilizable life of golden hamster ova and their morphological changes at the time of losing fertilizability. F. exp. Zool. 148, 185.

Yanagimachi, R. \& Ghang, M. C. (1963) Sperm ascent through the oviduct of the hamster and rabbit in relation to the time of ovulation. F. Reprod. Fert. 6, 413. 